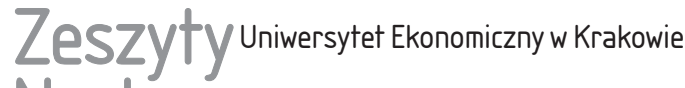 Naukowe
}

$8(944)$

ISSN 1898-6447

Zesz. Nauk. UEK, 2015; 8(944): 5-20 DOI: 10.15678/ZNUEK.2015.0944.0801

\author{
Leszek Kusak \\ Katedra Filozofii \\ Uniwersytet Ekonomiczny w Krakowie
}

\section{Miejsce nauk szczegółowych w filozofii Maxa Schelera ze szczególnym uwzględnieniem antropologii filozoficznej}

\section{Streszczenie}

Celem artykułu jest wyjaśnienie, na czym miałaby polegać, postulowana przez Schelera, współpraca filozofii z naukami szczegółowymi. Rozważania dotyczące poszczególnych rodzajów poznania prowadzą go do wniosku, że ani fakty nauk szczegółowych, ani też ich metody nie mogą być bezpośrednio wykorzystywane przez filozofię. Te pierwsze muszą zostać „oczyszczone” z obciążających je założeń i wszelkiego rodzaju „wtrętów”. Te drugie mogą pełnić rolę co najwyżej pomocniczą, gdyż główny ciężar odpowiedzialności za poznanie filozoficzne spoczywa na metodzie fenomenologicznej. Składają się na nią kolejno przeprowadzane redukcje (transcendentalna, psychologiczna, ejdetyczna), mające otworzyć nas na przestrzeń czystych możliwości. Metodologiczne postulaty Schelera nie zawsze są przez niego konsekwentnie wcielane w życie. W praktyce często odwołuje się on do faktów nauk szczegółowych i dokonuje indukcyjnych uogólnień, dotyczących problemów natury filozoficznej. Precyzyjnie przeprowadzone, wolne od założeń i nakierowane na istotę rzeczy doświadczenie fenomenologiczne nie jest zatem jedynym źródłem głoszonych przez niego tez.

Słowa kluczowe: nauki szczegółowe, naturalistyczne koncepcje człowieka, metody i formy poznania, rodzaje wiedzy, metoda fenomenologiczna. 


\section{Wprowadzenie}

Na przełomie XIX i XX w. wśród filozofów coraz bardziej upowszechniało się przekonanie o potrzebie nawiązania współpracy z naukami szczegółowymi. Sukcesy nauki przemawiały do wyobraźni, wyraźnie zaś widoczny zastój w filozofii dawał do myślenia. Dyskusja toczyła się wokół kwestii najważniejszej: jaki kształt powinna przybrać ta współpraca i jaką rolę miały w niej odgrywać obie strony. W praktyce wybierano różne rozwiązania włącznie ze skrajnymi, polegającymi bądź to na całkowitym podporządkowaniu filozofii nauce, bądź też na dominacji filozofii.

Wśród zwolenników wykorzystania potencjału nauki przez filozofię liczną grupę stanowili przedstawiciele fillozofii człowieka. Odkrycia medycyny, biologii, zoologii, anatomii porównawczej, fizjologii, prymatologii, psychologii i innych nauk zajmujących się badaniem świata istot żywych zostały przez nich dostrzeżone i docenione. „Kwestie te - jak podkreślał M. Scheler - posiadają nadzwyczajną filozoficzną doniosłość" [Scheler 1987b, s. 337]. Podobne stanowisko zajmowali m.in.: Helmuth Plessner, Arnold Gehlen, Adolf Portmann, Pierre Teilhard de Chardin, Karl Jaspers, Hannah Arendt i Hans Jonas.

Ważną rolę w tym gronie odegrał Max Scheler, który zajmował się problemem współpracy z naukami szczegółowymi zarówno na gruncie teorii, jak i praktyki. Stworzył nawet nową dyscyplinę filozofii, antropologię filozoficzną, która miała być ucieleśnieniem proponowanych przez niego zmian stosunku filozofii do nauki.

W sformułowanych przez Schelera założeniach programu antropologii filozoficznej wyraźnie widoczne jest przekonanie o potrzebie podjęcia przez nową dyscyplinę interdyscyplinarnych badań nad człowiekiem. Opierając się na ustaleniach nauk szczegółowych, miałaby się ona zająć badaniem stosunku człowieka do przyrody nieorganicznej, roślin i zwierząt oraz dążyć do ustalenia podstawowych kierunków i praw jego rozwoju biologicznego, psychicznego, historyczno-duchowego i społecznego (zob. [Scheler 1987a, s. 150-151]).

Miejsce i rola nauk szczegółowych, w uprawianej przez Schelera filozofii, wymaga jednak wyjaśnienia i doprecyzowania. Nie miał on bowiem zamiaru rezygnować z - przejawiającej się na różne sposoby - autonomii „królowej nauk". Do rozważenia tej kwestii dobrym punktem odniesienia są prace Schelera z zakresu antropologii filozoficznej. Pokazują bowiem, na czym w praktyce miałaby - według niego - polegać współpraca filozofii z naukami szczegółowymi. Szczególnie godne uwagi są te wypowiedzi Schelera, w których, odnosząc się do innych filozofów i koncepcji, nie tylko stara się pokazać, czym jego antropologia filozoficzna różni się od konkurencyjnych sposobów opisu człowieka (zarówno filozoficznych, jak i naukowych), lecz także wskazuje na dziedzictwo i współczesne dokonania, do których nawiązuje. 
Przedmiotem zainteresowania będą również rozważania Schelera o bardziej uniwersalnym, ogólnofilozoficznym charakterze na temat form i funkcji poszczególnych rodzajów wiedzy, relacji między nimi zachodzących i wynikającej z tego hierarchii. Rozważania te dostarczają cennych informacji na temat miejsca i rangi nauk szczegółowych w filozoficznej refleksji niemieckiego filozofa. Tak zamierzona rekonstrukcja, połączona z krytyczną analizą, powinna rozwiać (przynajmniej niektóre) wątpliwości dotyczące zasad i form współpracy między nauką i filozofią w ujęciu Maxa Schelera.

\section{Człowiek w świecie istot żywych}

Do podstawowych zagadnień antropologii filozoficznej należy kwestia miejsca człowieka w świecie istot żywych. Na problemie tym od wieków swoje zainteresowania skupiali filozofowie. Uwagi na temat uwarunowań biologicznych człowieka i zwierząt pojawiają się chociażby u Platona, Tomasza z Akwinu, Immanuela Kanta, Johanna Gottfrieda Herdera i Friedricha Nietzschego. Czy Scheler wniósł do tego zagadnienia coś nowego w stosunku do poprzedników? Czy wątek ten, ze względu na postulat ścisłej współpracy z naukami szczegółowymi, pełni istotną rolę w jego rozważaniach, czy też stanowi tylko wstęp do znacznie ważniejszych, czysto filozoficznych analiz?

Twórca antropologii filozoficznej w wielu wypowiedziach powtarza argumenty znane już z dzieł innych filozofów, dotyczące biologicznej niedoskonałości człowieka. Zwraca zatem uwagę na słabość jego zmysłów, niepewność instynktów, nieprzystosowanie do specyficznych warunków otoczenia, brak wyspecjalizowanych narządów. Wniosek płynący z tego opisu nie stanowi zaskoczenia:

$\mathrm{Z}$ punktu widzenia nauk przyrodniczych [...] jest on chorym zwierzęciem, które [...] pozostało daleko w tyle za swymi najbliżej z nim gatunkowo spokrewnionymi [zwierzęcymi] pobratymcami. Człowiek jest w rzeczy samej, dyletantem życiowym [Scheler 1987b, s. 332-333].

Z pewnością bardziej przekonująca jest argumentacja Schelera niż jego poprzedników. Powołuje się on bowiem na dobrze udokumentowane badania wybitnych specjalistów z zakresu anatomii porównawczej, fizjologii, medycyny i antropologii fizycznej. W istocie jest to jednak różnica drugorzędna. Treść argumentów bowiem nie uległa zmianie.

Scheler nie poprzestaje jednak na tym i przywołuje kolejne fakty nauk szczegółowych, które, jak się wydaje, pozwalają wykroczyć poza Herderowską ideę człowieka jako istoty ułomnej (Mängelwesen). Zwraca uwagę na niezwykle rozwiniętą, zróżnicowaną i zhierarchizowaną strukturę systemu nerwowego człowieka, w szczególności zaś jego kory mózgowej. U człowieka pojawiły się nowe, niewystę- 
pujące u zwierząt, części mózgu (np. płat skroniowy kory), mające istotne znaczenie dla rozwoju psychicznych funkcji i mentalnych osiągnięć gatunku ludzkiego.

Zdaniem Schelera wszystkie te innowacje nie stanowią jednak przełomu w rozważaniach na temat miejsca człowieka w świecie istot żywych. $Z$ czysto przyrodniczego punktu widzenia tak rozbudowany mózg nie jest bowiem atutem, lecz obciążeniem. Spożytkowuje on nadzwyczaj duże ilości energii, pozbawiając jej w ten sposób inne organy ${ }^{1}$.

Porównania sprawności człowieka i pozbawionych kresomózgowia zwierząt pouczają, iż człowiek jest niejako niewolnikiem swej kory mózgowej, organu, który w porównaniu z wszelkimi innymi organami ciała najmniej się regeneruje [...], w którym proces życiowy niejako całkowicie zastygł [Scheler 1987b, s. 336].

Również w tym fragmencie swoich rozważań Scheler podąża zatem tropem Herdera i Nietzschego. Wzmacnia siłę starych argumentów oraz dorzuca kolejne fakty przemawiające za znaną już ideą człowieka jako istoty naznaczonej brakiem. Jego wywody mieszczą się w ramach empiryczno-opisowej koncepcji człowieka.

Nie może zmienić tej opinii kolejny, nieco przewrotny w swej istocie, pomysł Schelera, aby na tle niezbyt optymistycznego obrazu człowieka jako istoty naznaczonej brakiem podkreślić dokonania natury w odniesieniu do całej reszty świata organicznego. Powołując się na badania Wolfganga Köhlera (1887-1967)² i Friedricha Alverdesa (1889-1952) ${ }^{3}$, Scheler wskazuje na konieczność zrewidowania dotychczasowych opinii na temat psychologicznych zdolności zwierząt. Przez długi czas sądzono, że zachowanie zwierząt jest determinowane (prawie) wyłącznie przez instynkty i pamięć asocjacyjną ${ }^{4}$. Najnowsze badania nauk

${ }^{1}$ Mózg, który stanowi zaledwie 2\% masy ciała, zużywa 20\% energii, którą ma ono do dyspozycji.

2 W. Köhler - niemiecki psycholog, jeden z twórców Gestaltpsychologie - zasłynął prowadzonymi w latach 1913-1917 na Teneryfie badaniami szympansów. Odkrył, że cechuje je zdolność inteligentnego zachowania umożliwiającego rozwiązywanie różnorodnych, niekiedy nawet dosyć skomplikowanych, problemów życia codziennego. Zdolność tę określił terminem „wgląd” (Einsicht). Opis oraz wnioski ze swoich badań przedstawił w pracy Inteligenzprüfungen an Anthropoiden (1917). Cztery lata później ukazało się drugie, poszerzone wydanie pod zmienionym tytułem: Inteligenzprüfungen an Menschenaffen. Mit einem Anhang zur Psychologie des Schimpansen (1921).

${ }^{3}$ F. Alverdes - niemiecki zoolog i psycholog, wykazał w swoich badaniach, że dla zrozumienia zachowania się niższych organizmów konieczne jest założenie, że dysponują one zdolnościami, które dotąd przypisywano tylko wyżej rozwiniętym gatunkom zwierząt. Główne tezy swojej koncepcji przedstawił w pracy Neue Bahnen in der Lehre von Verhalten der niederen Organismen (1923).

${ }^{4}$ Instynkty rozumiane były jako,,wrodzona, przekazywana dziedzicznie zdolność trafnego (sinnvoll) radzenia sobie z typowymi, stale powtarzającymi się sytuacjami za pomocą właściwych dla każdego gatunku, ściśle zrytmizowanych, kolejnych sposobów zachowań” [Scheler 1987b, s. 344-345]. Z kolei pamięć asocjacyjna (skojarzeniowa) traktowana była jako świadectwo wyższych procesów psychicznych, które rozwinęły się tylko u nielicznych gatunków zwierząt. Pozwa- 
szczegółowych - według Schelera - uzasadniają tezę, że zdolności niektórych gatunków zwierząt wykraczają daleko poza tego typu determinacje. W grupie małp człekokształtnych wyraźnie widoczne są początki inteligencji technicznej, rozumianej jako ,zdolność do zachowania, które w sposób biologicznie celowy (biologisch sinnvoll) potrafi sprostać nowym, nietypowym sytuacjom bez nowych prób i błędów i bez wprawiania się" [Scheler 1987b, s. 338] oraz „związana z nią zdolność trafnego wyboru o kierunku nie wyznaczonym [z góry] przez sztywną, typową organizację gatunkową" [Scheler 1987b, s. 345]. Praktyczna inteligencja techniczna nie jest zatem, jak dotąd sądzono, jednym z wyróżników człowieczeństwa - „u człowieka jest ona jedynie nadzwyczaj spotęgowana w sensie ilościowym, niekiedy aż do poziomu [...] Siemensa czy Edisona" [Scheler 1987b, s. 346].

Zwierzęta potrafią również posługiwać się pewnymi rzeczami, jak narzędziami i są zdolne do czynności altruistycznych, niezależnych od okresu godowego i instynktu opieki nad potomstwem. Zdaniem Schelera nie można im także odmówić „,zdolności przedkładania jednego dobra nad inne, np. pewnego pożywienia nad inne [...] oraz wybierania spośród wielu czynności tych, które obiecują osiągnięcie tego, co jest przez nie preferowane" [Scheler 1987b, s. 346].

Docenienie możliwości zwierząt przez Schelera wiązało się bezpośrednio z najnowszymi osiągnięciami nauk zajmujących się badaniem ich budowy i zachowania. W pewnym sensie wpisywało się w tok myślenia coraz liczniejszego od czasów Darwina grona badaczy, którzy krok po kroku unicestwiali kolejne bariery „odgradzające” świat zwierząt od świata ludzkiego. Czy jednak rzeczywiście stanął on tym samym po stronie zwolenników naturalistycznych koncepcji człowieka? Czy na tym właśnie w praktyce miałaby polegać postulowana przez Schelera współpraca antropologii filozoficznej z naukami szczegółowymi? Czy filozofia miałaby zrezygnować ze swych ambicji poznawczych, zadowalając się zadaniem indukcyjnego uogólniania naukowych faktów?

\section{Krytyka naturalistycznych koncepcji człowieka}

Scheler nie podzielał poglądu, że nauka wytyczyła już prostą drogę wiodącą od zwierzęcia do człowieka, że dokonała się swego rodzaju unifikacja tych dwóch światów. Swoje zastrzeżenia i wątpliwości sformułował w polemice z obrońcami koncepcji człowieka jako homo naturalis. Prowadzone przez naukowców badania

lała ona wyjaśnić zdolność uczenia się za pomocą nagród i kar oraz za pomocą „prób i błędów”, a także utrwalania przynoszących sukces sposobów zachowania. Badania nad tym zjawiskiem, dobrze znane Schelerowi, zapoczątkowane zostały przez rosyjskiego fizjologa Iwana Pawłowa (1849-1936) i amerykańskiego psychologa Edwarda Thorndike’a (1874-1949). 
małp człekokształtnych z jednej strony dowartościowały naczelne, z drugiej jednak - zdaniem Schelera - wskazały granice, których zwierzęta nie są w stanie przekroczyć. Wyraźnie widać to w odniesieniu do narzędzi i języka.

Według Schelera zwolennicy poglądu, jakoby wyższe gatunki zwierząt posiadły zdolność tworzenia narzędzi i operowania nimi, nie tylko przeceniają ich możliwości, lecz także nie rozumieją pojęcia „narzędzie”. Niektóre zwierzęta są w stanie manipulować i poruszać przypadkowymi przedmiotami dla osiągnięcia jakiegoś witalnie ważnego celu, ale przez to przedmioty te nie stają się jeszcze narzędziami. Narzędzie cechuje bowiem:

[...] trwała jedność materialnej formy i związanego z nią sensu. To twór posiadajqcy sens, wtórnie oddany w służbę celów, który wykazuje bezinteresowny charakter jakiegoś małego dzieła sztuki, zaś swój ostateczny sens i wartość uzyskuje jedynie jako „droga do kultury" i odpowiadającej jej swobodnej aktywności duchowej [Scheler 1987c, s. 21].

Również język zaliczany jest przez Schelera do zbioru „monopoli” człowieka. Przemawiają za tym nie tylko filozoficzne argumenty, lecz również badania prowadzone przez prymatologów, psychologów i językoznawców ${ }^{5}$. Żyjące na wolności społeczności małp człekokształtnych posługują się systemem sygnałów, który umożliwia wyrażanie i komunikowanie się. Funkcje te - jak wynika to z badań Köhlera - są jednak realizowane na poziomie elementarnym, podporządkowane są potrzebie zdobycia pokarmu i instynktom społecznym (agresja, rozmnażanie się). Nieobecna jest w tym systemie, kluczowa dla języka, funkcja przedstawiania. Funkcja ta, występująca w ludzkim języku, nie ogranicza się do uobecniania tego, co jest przedmiotem doświadczenia zmysłowego lub też podsuwane jest przez pamięć i wyobraźnię. Obejmuje bowiem także przedmioty, które jawią się bez tego rodzaju pośrednictwa, są zaś domeną myślenia występującego w formie wyjaśnień i uzasadnień, ujmowania struktur i ontologiczno-epistemologicznych modalności (rzeczywisty-możliwy-konieczny itp.) (zob. [Haeffner 2006, s. 56-68]).

Miano języka przysługuje zatem systemowi znaków, który spełnia wszystkie przypisane językowi funkcje i ma określoną wewnętrzną strukturę wyrażającą się w gramatyce i słowniku. Spośród znanych nam istot językiem dysponuje wyłącznie homo sapiens.

Scheler uznaje za chybione próby wywiedzenia ludzkiej mowy z ,utrwalonych i automatycznie powtarzających się w tych samych okolicznościach „objawów wyrazowych” i „sygnałów”, jakimi dysponują najwyższe zwierzęta” [Scheler

5 Klasyczne ustalenia dotyczące atrybutów języka są dziełem W. von Humboldta (1767-1835), który w pracy Über die Verschiedenheit des menschlichen Sprachbaues und ihren Einfluss auf die geistige Entwicklung des Menschengeschlechts (1824-1828) wyróżnił trzy jego funkcje: wyrażanie (wewnętrznych stanów mówiącego), komunikowanie się (podmiotów) i przedstawianie (stanów rzeczy). 
1987c, s. 19]. Drugorzędne znaczenie mają podnoszone przez przyrodników różnice anatomicznych i fizjologicznych właściwości narządów mowy zwierząt i człowieka. „Zdolność artykułowania dźwięków jest tylko następstwem sensownego uczłonowania, przez pryzmat którego człowiek ujmuje dane świata zewnętrznego i wewnętrznego" [Scheler 1987c, s. 17]. „Na początku języka było słowo! Zwierzę nie „mówi” dlatego, że nie posiada słowa” [Scheler 1987c, s. 20]. „Człowiek jest człowiekiem tylko dzięki mowie; aby jednak wynaleźć mowę, musiał już być człowiekiem" [Scheler 1987c, s. 20] - kończy swój wywód Scheler, cytując słowa Wilhelma von Humboldta.

Przyrodnicze koncepcje traktują człowieka ,jako późny rezultat ewolucji życia na ziemi”, który dzięki „mądrości natury” zajął wyróżnioną pozycję w świecie istot żywych. Scheler kwestionuje zasadność takiego ujęcia. Wbrew intencjom autorów nie jest ono świadectwem postępu, lecz regresu życia, które w człowieku wyczerpało już swoje witalne zdolności rozwoju i „zabrnęło w ślepą uliczkę”. Intelekt mający zastąpić nieobecny lub niepewny instynkt jest - jak podkreśla Scheler - tylko „cnotą błędu”, narzędzie zaś - jedynie surogatem „wybrakowanych narządów". Cały wysiłek natury w odniesieniu do człowieka, jej pomysłowość i przebiegłość, zmierza do celu, który zwierzęta osiągają bez wysiłku, niejako automatycznie. Celem tym - zgodnie z naturalistyczną koncepcją człowieka - jest przystosowanie do środowiska, przetrwanie w walce o byt. „Zwierzę posługujące się intelektem i wytwarzające narzędzia”, mierzone „zachowaniem życia” i jego celami, nie jest koroną witalnego rozwoju, lecz chorym stworzeniem, „w którym życie popełniło faux pas". Tym bowiem sposobem skomplikowanymi i okrężnymi drogami człowiek osiągnął ,nie więcej - jeśli wziąć pod uwagę jedynie punkt widzenia przyrodoznawstwa - aniżeli zwierzę osiąga o wiele prościej w sposób bardziej automatyczny, wiedzione swymi instynktami" [Scheler 1987b, s. 338] ${ }^{6}$.

Głównym punktem odniesienia naturalistycznych koncepcji człowieka jest idea zachowania gatunku i realizacji specyficznie biologicznych wartości. W tych ramach - jak podkreśla Scheler - człowiek pozostaje jednak zwierzęciem, i to zwierzęciem ułomnym! Żadna, nawet wąska ścieżka nie prowadzi „od homo naturalis i jego hipotetycznie skonstruowanej prehistorii do «człowieka» historii”, którego możemy pojąć na podstawie zabytków kultury materialnej i duchowej, dokumentów pisanych i tradycji. Dlatego też - jak twierdzi Scheler - „każdy

${ }^{6} \mathrm{Z}$ naturalistyczną koncepcją człowieka polemizował już Immanuel Kant. W Uzasadnieniu metafizyki moralności sformułował myśl, którą w swoich wywodach rozwija i uzasadnia Scheler: „Gdyby w istocie posiadającej rozum i wolę właściwym celem przyrody było jej utrzymanie, dobre powodzenie, słowem jej szczęśliwość, to przyroda poczyniłaby bardzo złe przygotowania do tego celu, obierając rozum stworzenia na wykonawcę tego zamiaru. Albowiem wszystkie czynności, które istota ta ma wykonać, i całe prawidło jej zachowania się wyznaczyłby jej znacznie dokładniej instynkt, i cel ów dałby się przez to daleko pewniej osiągnąć, aniżeli stać się to może kiedykolwiek za pomocą rozumu" [Kant 2001, s. 12-13]. 
problem, który pojawia się w obrębie granicy tzw. przejścia człowieka od stanu natury do stanu kultury [...], a więc również kwestie tzw. powstania państwa, języka, prawa itd. - postawiony jest błędnie i fałszywie, o ile daje się mu historyczne wyjaśnienie" [Scheler 1987c, s. 19] $]^{7}$. Mają one bowiem naturę metafizyczną czy też, mówiąc ogólniej, filozoficzną.

Antropologia filozoficzna, w ujęciu Maxa Schelera, programowo kładzie nacisk na współpracę filozofii z naukami szczegółowymi. Dzięki idei Mängelwesen nauki te na dużą skalę wkraczają do rozważań filozoficznych, ich rola nie jest jednak samodzielna ani też pierwszoplanowa. Same w sobie nie są one w stanie stworzyć ogólnej, całościowej koncepcji człowieka. Zamiast traktować go indywidualnie, próbują one ująć człowieka w kategoriach przynależnych prostszym formom istnienia. Tracą przy tym z pola widzenia, co dla niego swoiste. W pewnym sensie eliminują z opisu świata niepowtarzalne zjawisko, jakim jest człowiek.

Scheler, dostrzegając to zagrożenie, krytykuje przyrodnicze koncepcje człowieka za ich „zoocentryczny redukcjonizm”, podporządkowywanie pojęcia człowiek pojęciu zwierzę. Niemiecki filozof nie ma wątpliwości, że systematyczno-przyrodnicze koncepcje człowieka ujmują go poniżej jego poziomu, prowadząc do „uzwierzęcenia” homo sapiens.

\section{Metody i formy poznania}

Krytyczne stanowisko Schelera wobec naturalistycznych koncepcji człowieka nie wynikało z nieznajomości metod i form naukowego poznania czy też niedoceniania osiągnięć nauk szczegółowych. Niemiecki filozof odrzucał jednak, pojawiające się zarówno w nauce, jak i w filozofii, postulaty podporządkowania filozofii nauce, ograniczenia jej obszaru badań, czy też narzucenia jej norm i rygorów naukowej metodologii. Scjentystyczno-pozytywistyczny program filozofii jako dyscypliny ograniczającej się do logicznej analizy języka, bądź też „rozpływającej się w teorii poznania i psychologii eksperymentalnej” był dla niego świadec-

7 Scheler zgłaszał poważne wątpliwości dotyczące dominującego w nauce obrazu genezy człowieka, nie kwestionując przy tym samej idei ewolucji. Sposób objaśniania przejścia między światem zwierząt a homo sapiens wydawał mu się nadmiernie uproszczony, zaś przyjęte założenia - pełne luk. Powoływał się przy tym m.in. na prace niemieckiego badacza antropogenezy Hermanna Klaatscha (1863-1916). Ten wybitny antropolog, lekarz i specjalista anatomii porównawczej prowadził badania terenowe w Australii. Był autorem wielu prac z zakresu anatomii porównawczej naczelnych, z których sławę przyniosła mu przede wszystkim Die Stellung des Menschen im Naturganzen (1911). Kwestionował w niej tezę o pochodzeniu człowieka od małpy. Zdaniem Klaatscha zakładana w tym wypadku „okrężna droga”, która poprzez zwierzęta nadrzewne i wspinające się miałaby prowadzić do homo sapiens wymagałaby odpowiedniego przystosowania się, które musiałoby pozostawić ślady w anatomii człowieka. 
twem niezrozumienia natury i celów „królowej nauk”. „Filozofii - jak podkreślał Scheler - nie wolno być zwykłą służebnicą nauki, podobnie jak nie wolno jej być służebnicą kościelnej wiary" [Scheler 1987d, s. 412].

Scheler nie tylko bronił autonomii filozofii, lecz także podkreślał jej szczególną pozycję w stosunku do nauk pozytywnych. Uzasadniał to m.in. w swojej koncepcji form poznania i rodzajów wiedzy. Jego zdaniem poznanie ludzkie może przybierać trzy zasadnicze formy: naturalnego światopoglądu, nauki i filozofii. Każde z nich przebiega inaczej i prowadzi do odmiennych rezultatów.

Naturalny światopogląd ma charakter antropocentryczny i ściśle wiąże się z biologiczną konstrukcją człowieka. Jego źródłem są „,naturalne spostrzeżenia” i „naturalne myślenie” (tzw. zdrowy rozsądek). Naturalny światopogląd znajduje wyraz w mowie potocznej, w kategoriach i zwrotach opisujących świat rzeczy i procesów, których „oczywistość” nie podlega dyskusji. Jego wpływ na naukę i filozofię, jeszcze do niedawna znaczny, stopniowo ulega ograniczeniu.

Naukowy obraz świata cechuje ,sztuczność”. Miejsce „,naturalnego spostrzeżenia” zajmuje w nim „obserwacja”. Bezpośrednim przedmiotem naukowego poznania i punktem wyjścia do dalszych analiz nie są już rzeczy i procesy, lecz stany, których rzeczy są nosicielami. Rzeczy nie są zatem „dane”, lecz są „konstruowane” i „pośrednio pomyślane”. Metoda naukowego postępowania jest ściśle określona: albo indukcyjna albo aksjomatyczno-dedukcyjna. Nauka programowo abstrahuje od świata wartości i stara się eliminować (lub neutralizować) wszelkie antropomorfizmy i antropocentryczne skłonności. Mimo wielu różnic, wspólne dla naturalnego światopoglądu i nauki jest to, że w obu tych formach poznania fakty nie są dane bezpośrednio, lecz zawsze pośrednio za pomocą znaków i symboli.

Filozofia - według Schelera - różni się od „naturalnego światopoglądu” oraz nauki zarówno sposobem poznawania, jego przedmiotem, jak i „uposażeniem” podmiotu poznającego. Właściwym dla filozofii sposobem poznania jest - jak twierdzi Scheler - poznanie fenomenologiczne, przedmiotem są fenomeny, zaś wstępnym jego warunkiem jest wewnętrzne przeobrażenie poznającego.

Utożsamienie przez Schelera filozofii z fenomenologią określa kształt jej relacji z nauką. Wyjaśnia powody, dla których antropologia filozoficzna - w wersji Schelerowskiej - niejako z definicji nie może bezkrytycznie odwoływać się do jednostkowych faktów nauk szczegółowych, nie może też mieć zaufania do stosowanych przez nie metod wnioskowania.

Twórcą fenomenologii był Edmund Husserl. Na początku XX w. przedstawił on program filozofii jako nauki ścisłej (opierającej się na powszechnie ważnych i oczywistych pryncypiach), dostarczającej podstaw wszystkim dyscyplinom (filozofia pierwsza) i niezależnej od innych nauk [Husserl 1901, t. 1-2]. Główną rolę w tym programie odgrywa poznanie fenomenologiczne. Przebiega ono w trzech 
następujących po sobie krokach, które w sposób zasadniczy przeobrażają podmiot i przedmiot poznania.

Pierwszy krok to tzw. redukcja transcendentalna. Polega ona na uchyleniu tezy należącej do istoty naturalnego nastawienia, mianowicie tezy o istnieniu świata. Uchylenie nie oznacza przy tym niszczącej negacji, lecz neutralizację niepoddanych krytyce treści. Husserl mówi w tym wypadku o „wzięciu w nawias”(Inklammersetzung), „wyłączeniu”(Ausschaltung), ,zawieszeniu”(epoche).

Krok drugi określany jest jako redukcja psychologiczna. Oznacza ona przekierowanie doświadczenia, odwrócenie się od przedmiotów ku aktom świadomości, w których są one uchwytywane. Redukcja psychologiczna prowadzi do ostatecznego uwolnienia się od świata oraz poszerzenia i intensyfikacji doświadczenia, wydobycia innej jego modalności. Przedmiot nie jest już ujmowany sam w sobie, lecz poprzez akty świadomości, które go domniemują.

Krok trzeci nazywany jest redukcją ejdetyczną (ideacja). Jest to akt myślowy, który, znajdując oparcie w danych wrażeniowych, zmierza do wypreparowania istoty danego fenomenu. Główną rolę odgrywają w nim percepcja i wyobraźnia. Ta pierwsza zakorzenia poznanie fenomenologiczne w doświadczeniu, ta druga - wyprowadza poza jego jednostkowość. Otwarcie się na przestrzeń czystych możliwości, będące zasługą wyobraźni, pozwala dotrzeć do sfery tego, co stanowi eidos, tj. istotę ogólną.

Stanowisko Schelera w kwestiach epistemologicznych pod pewnymi względami różni się od poglądów Husserla. Jego wątpliwości dotyczyły przede wszystkim możliwości i potrzeby przeprowadzania daleko idącej redukcji transcendentalnej. Twórca antropologii filozoficznej podkreślał, że postawę fenomenologiczną zajmuje konkretny człowiek związany w rozmaity sposób ze światem. Różnym rejonom bytu odpowiadają zaś różne formy doświadczenia, różne rodzaje aktów. W poznanie musi być zatem zaangażowana cała osoba ludzka, a nie tylko jakaś jedna jej funkcja, czy też „czyste Ja”.

Dotarcie do bytu wymaga od osoby szczególnego „wzlotu”. W ujęciu Schelera jest to akt o charakterze moralnym, którego najistotniejszym warunkiem jest miłość duchowej osoby do bytu. Wydobywa ona obiekty z mroku, czyniąc je dostępnymi intelektualnej analizie („Wszędzie miłośnik poprzedza znawcę”). W nauce ta forma miłości nie jest potrzebna, dążenie badacza do wiedzy jest bowiem ożywione miłością do poznania rzeczy. Na rezultaty działalności poznawczej - zdaniem Schelera - większy wpływ mają zatem kwalifikacje moralne człowieka aniżeli bezbłędnie i do końca przeprowadzona redukcja transcendentalna.

Główną rolę w metodzie fenomenologicznej stosowanej przez Schelera odgrywa redukcja ejdetyczna. Jest to procedura, której celem jest przezwyciężenie naszego przywiązania do szczegółowych danych zmysłowych i otwarcie się na przestrzeń czystych możliwości. Nie oznacza ona jednak przyzwolenia na czystą 
spekulację. Poznanie fenomenologiczne - według Schelera - jest formą „radykalnego empiryzmu" ${ }^{8}$. Odwołuje się ono nie tylko do doświadczenia zmysłowego i doświadczenia wewnętrznego (introspekcja), lecz także do innych form kontaktu poznawczego z przedmiotem, które realizują się w postaci „świadomości czegoś" (intelektualne przedstawienie, emocjonalne czucie czegoś, kochanie, chcenie). Ile jest odmian aktów, tyle jest odmian doświadczenia.

Celem redukcji ejdetycznej jest wykroczenie poza sferę jednostkowych faktów i uchwycenie ogólnej istoty badanego fenomenu. Różnicę między fenomenologią a skupioną na faktach nauką trafnie ujął Husserl w Ideach I. Dla twórcy fenomenologii fakt jest abstrakcją (jego rzeczywistość ograniczona jest do jednej możliwej aktualizacji wykluczającej wszelkie inne możliwości), istota zaś konkretem (uwzględnia nieskończoną liczbę odmian tego, co rzeczywiste).

Swoiste dla fenomenologii (a obce nauce) jest też połączenie empiryzmu $\mathrm{z}$ aprioryzmem. Doświadczenie fenomenologiczne jest wglądem w istotę (Wesensschau), nie ma charakteru indukcyjnego, ani też dedukcyjnego. Momenty aprioryczne są wydobywane $\mathrm{z}$ fenomenu, a nie są mu narzucane przez umysł.

Fenomenologia - zgodnie z deklaracjami jej twórców - umożliwia dostęp do czystego, wolnego od założeń i absolutnego poznania. To radykalne w swej istocie przesłanie stoi w jawnej sprzeczności z praktyką i metodologicznymi założeniami nauk szczegółowych. Stawia też pod znakiem zapytania możliwość odegrania przez nie istotnej roli w badaniach prowadzonych przez Schelera.

\section{Rodzaje wiedzy}

Nauka i filozofia różnią się - według Schelera - nie tylko metodami i formami poznania, lecz także rodzajem zdobytej wiedzy i jej wartością (ze względu na cel, któremu ma służyć). Celem nauki jest zdobycie wiedzy umożliwiającej techniczne panowanie nad naturą, historią i społeczeństwem, czyli wiedzy dającej władzę. Panować zaś można nad zjawiskami, które daje się przewidywać. Nauki szczegółowe koncentrują zatem swój wysiłek na poszukiwaniu praw rządzących sztucznie uporządkowanym w klasy zjawisk światem, uposażonym w przypadkowe, przysługujące mu „tu i teraz” właściwości. Filozofia dąży w pierwszej kolejności do wiedzy kształcącej, która różni się zasadniczo od wiedzy nauk szczegółowych.

Wiedza kształcąca, ,jest uzyskaną i przyswojoną na przykładzie jednego lub niewielu odpowiednich, wyrazistych egzemplarzy jakiejś rzeczy, wiedzq dotyczq̨cq tego, co istotowe, wiedzą, która stała się formą i regułą pojmowania,

${ }^{8} \mathrm{Na}$ temat różnic między doświadczeniem fenomenologicznym a innymi formami doświadczenia zob.: [Węgrzecki 1975]. 
„kategorią”, pod którą w przyszłych doświadczeniach podciągane są wszystkie przypadkowe fakty tego samego typu" [Scheler 1987b, s. 364].

Wiedza kształcąca - jak podkreśla Scheler - zajmuje wyższe miejsce w hierarchii wiedzy aniżeli wiedza dająca władzę. Ta ostatnia służy jedynie opanowywaniu i praktycznemu przekształcaniu świata. Tymczasem dzięki wiedzy kształcącej ,poszerzamy oraz rozwijamy byt i uposażenie jakościowe duchowej osoby w nas, [niejako czyniąc ją] mikrokosmosem", zapewniając sobie przez to „udział w totalności świata" [Scheler 1987b, s. 372].

Poznania, które owocują wiedzą kształcącą, mają dwojakie zastosowanie. „W odniesieniu do każdego obszaru nauk pozytywnych (matematyka, fizyka, biologia, psychologia itd.) zakreślają one główne założenia odnośnego obszaru badań. Tworzą one jego «istotową aksjomatykę»" [Scheler 1987d, s. 421]. Dla samej metafizyki zaś są one tym, co Hegel nazwał kiedyś „oknem na absolut”. Prowadzą do wiedzy wyzwalającej, wiedzy w najwyższym tego słowa znaczeniu metafizycznej ${ }^{9}$.

Wiedza kształcąca, czyli dotycząca tego, co istotowe, określana jest przez Schelera - w nawiązaniu do Arystotelesa - jako ,pierwsza filozofia”, jako „ontologia świata i jaźni”. Nie jest ona jeszcze metafizyką samą, ale jest odskocznią do wiedzy „metafizycznej i wyzwalającej”, która występuje w postaci metafizyki pierwszego szczebla oraz metafizyki drugiego szczebla. Powiązanie rezultatów nauk pozytywnych z ,pierwszą filozofią" oraz z wynikami dyscyplin aksjologicznych (etyki, estetyki, teorii kultury, ogólnej teorii wartości) prowadzi ku metafizyce „problemów granicznych” nauk pozytywnych (czym jest „życie”?, czym jest „materia”?), czyli ku metafizyce ,pierwszego szczebla”. Z tego poziomu - zdaniem Schelera - można dopiero wznieść się ku metafizyce absolutu, czyli metafizyce „drugiego szczebla”. Dotyczy ona prabytu, absolutu, w którym zakorzeniona jest istotowa struktura obiektywnego świata, zasady wszystkich zasad, która sama nie może już być uprzedmiotowiona.

Droga od metafizyki „problemów granicznych” ku metafizyce absolutu prowadzi poprzez antropologię filozoficzną. Jej główne pytanie: „czym jest człowiek?" - ogniskuje w sobie wszystkie najważniejsze problemy filozoficzne. W człowieku spotykają się bowiem wszystkie istotowe stopnie bytu (fizykalny, chemiczny, organiczny i duchowy) i stosują się do niego wszystkie znane nam typy praw (mechaniczne, fizyczne, chemiczne, biologiczne, psychologiczne i noetyczne) (zob. [Scheler 1987c, s. 330]). Człowiek jest „światem w miniaturze”, jest „mikrokosmosem”, na przykładzie którego można studiować „makrokosmos” i poprzez który można uzyskać dostęp do absolutu.

9 „Wiedza wyzwalająca może być jedynie wiedzą o istnieniu, istocie i wartości tego, co absolutnie realne we wszelkich rzeczach, a to znaczy: wiedzą metafizyczną" [Scheler 1987b, s. 380]. 
Metafizyka „drugiego szczebla” - w ujęciu Schelera - „nie jest już kosmologią i metafizyką przedmiotu, lecz metaantropologiq i metafizyką aktu". Jej ukoronowaniem nie jest jakikolwiek rodzaj wiedzy teoretycznej, przedmiotowej, gdyż „najgłębsza podstawa tego wszystkiego, co poddaje się uprzedmiotowieniu, sama mu się nie poddaje" [Scheler 1987d, s. 426]. Dostęp do absolutu zapewnia jedynie aktywny udział człowieka $\mathrm{w}$ procesie stawania się, samourzeczywistniania się prabytu. Człowiek nie jest zatem tylko biernym obserwatorem zewnętrznych wobec niego zdarzeń, lecz współtwórcą i współwykonawcą dynamicznego procesu rozwoju świata, w którym prabyt urzeczywistnia i poznaje swoją czystą istotę.

Wnioski Schelera są zatem jednoznaczne. Nauka różni się od filozofii zarówno jeśli chodzi o formę, przedmiot, jak i rezultaty poznania. Filozofia dysponuje własnymi narzędziami i metodami, sięga głębiej, jej wiedza ma charakter ponadczasowy i wykracza swoim znaczeniem daleko poza utylitarnie ukierunkowaną naukę. Filozofia zakreśla ramy funkcjonowania nauki, niczego w zamian nie oczekując.

\section{Uwagi końcowe}

Naukę i filozofię, w ujęciu Schelera, zdecydowanie więcej dzieli niż łączy. Niemiecki filozof pisze o tym wprost. „Pomimo wszelkiej koniecznej bliskiej kooperacji filozofii z nauką ich cele i kryteria poznawcze są sobie wręcz przeciwstawne” [Scheler 1987b, s. 376]. Nauka stawia pytanie „dlaczego”, gdy zaskakują ją zdarzenia wykraczające poza „regularny” bieg rzeczy, gdy zawodzą empirycznie sprawdzone i obowiązujące dotychczas schematy przewidywania. Gdy to, co "nowe" i zaskakujące, uda się wkomponować w zmodyfikowany obraz uporządkowanego, rządzonego ,prawami przyrody” świata, nauka jest usatysfakcjonowana. Dopiero w tym miejscu - według Schelera - rozpoczyna się aktywność filozofii. Abstrahuje ona od realnego istnienia rzeczy. Nie interesują jej też „prawa czasoprzestrzennej koincydencji ujmowanych ilościowo zjawisk", lecz trwała „istota” i pochodzenie zjawisk o tej właśnie istocie, a także „,sens $i$ cel tego, co się oto $w$ ogóle pojawia - całkiem obojętne, w jakim czasoprzestrzennym związku i w jakiej ilości” [Scheler 1987b, s. 377]. Filozofia pyta, czym są te związki, co oznaczają, co jest ich istotowo ujętą przyczyną. Tymczasem nauka w ogóle nie stawia pytań o istotę obiektów, którymi się zajmuje. Jej przedmiotem jest świat zrelatywizowanych w swym istnieniu zjawisk ujmowanych poprzez obserwację, pomiar i matematyczne wnioskowanie. Pytania, które wykraczają poza ten obszar nie są pytaniami nauki i nie mają dla niej żadnego sensu.

Filozofia Schelera zawiera założenia, które mogą świadczyć o otwartości na dokonania nauki, w praktyce jednak utrudniają współpracę między tymi dyscy- 
plinami. Z jednej bowiem strony fenomenologiczny opis wymaga przechodzenia w poprzek wielu różnych dyscyplin (nauki przyrodnicze, etnografia, teoria języka, malarstwo), wymaga konfrontacji z niefilozoficznymi formami dyskursu, z drugiej zaś - konfrontacja ta nacechowana jest poczuciem wyższości metody i wiedzy filozoficznej, która dopuszcza zakorzenienie w naukach szczegółowych wyłącznie na zasadzie autonomicznej partycypacji.

Kreślony przez Schelera obraz relacji między filozofią (antropologią filozoficzną) i nauką nie jest jednak przypadkowy. Kryje się za nim wiele założeń, z których dwa pełnią główną rolę. Po pierwsze, empiryczne fakty nauk szczegółowych, ograniczające się w każdym pojedynczym przypadku do jednej, wykluczającej wszelkie inne możliwości aktualizacji, wzięte w swym uwikłaniu w różnorakie, wypowiedziane i niewypowiedziane założenia, nie mogą być - zdaniem Schelera - bezpośrednio wykorzystywane w filozofii. Konieczne jest ich „oczyszczenie", neutralizacja niepoddanych krytyce treści, mniej lub bardziej zaawansowane epoche. Po drugie, nie można przenieść na grunt filozofii powszechnie stosowanych w nauce metod wnioskowania (takich jak indukcja czy dedukcja). Metody te spełniają swoją rolę wszędzie tam, gdzie na plan pierwszy wysuwa się ilościowe ujęcie zjawisk, gdzie obowiązują empiryczne schematy uzasadniania i przewidywania. Filozofia - utożsamiana przez Schelera z fenomenologią - zainteresowana jest jednak poszukiwaniem trwałej istoty badanych obiektów, objaśnieniem porządku rzeczy istotnościowo różniącego się od sfery przyrody (kultura, duch, religia). Jej celem jest wiedza wyrażona w sądach syntetycznych a prori.

Metodologiczne postulaty Schelera nie zawsze jednak są przez niego konsekwentnie wcielane w życie. W praktyce często odwołuje się on do empirycznych faktów nauk szczegółowych, dokonując indukcyjnych uogólnień, dotyczących swoistości, struktury i form aktywności człowieka. Precyzyjnie przeprowadzone, wolne od założeń i nakierowane na istotę rzeczy, doświadczenie fenomenologiczne nie jest zatem jedynym źródłem głoszonych przez niego tez.

Droga w przeciwnym kierunku wydaje się u niego również otwarta. Wiedza zdobyta za pomocą doświadczenia fenomenologicznego potrzebuje niekiedy, z troski o niesprzeczność rezultatów filozoficznych rozważań z konkluzjami nauk szczegółowych, pewnego rodzaju uwiarygodnienia - zwłaszcza gdy rezultaty poznania ejdetycznego nie są jednoznaczne lub nawet się wykluczają. Wtedy właśnie z pomocą przychodzą nauki szczegółowe, które pozwalają Schelerowi korygować niektóre wnioski poznania ejdetycznego.

Wątpliwości budzi też przekonanie jakoby metoda fenomenologiczna stanowiła domenę filozofii utożsamianej z fenomenologią. Zdaniem wybitnego logika, przedstawiciela filozofii analitycznej, dominikanina Józefa Marii Bocheńskiego metoda ta nie tylko stosowana jest przez większość współczesnych filozofów (a nie tylko fenomenologów), lecz także przez naukowców. „Prawie wszystkie reguły metody 
fenomenologicznej można byłoby uznać za ogólne reguły naukowe" [Bocheński 1992, s. 29]. Ich znaczenia nie pomniejsza fakt, że niekiedy nie jesteśmy w stanie sprostać stawianym przez nie wymaganiom. Obiektywnie „są to ważne, ogólnie obowiązujące reguły myślenie teoretycznego" [Bocheński 1992, s. 29].

Scheler przedstawił szeroką panoramę historycznie ugruntowanych relacji i związków między filozofią a naukami szczegółowymi. Wyłaniają się z niej pewne kluczowe elementy, które tworzą niejednoznaczną i wymagającą dalszych dyskusji całość. Niemiecki filozof nie kryje, że współpraca filozofii z naukami szczegółowymi może być płodna, że naukowe paradygmaty opisu (etnograficzny, neurobiologiczny, psychologiczny, kosmologiczny itd.) wzbogacają podejście filozoficzne o empirię, gwarantują jej żywotność, niekiedy nawet stanowią kryterium oczywistości i sensowności podjęcia danego problemu. Mimo to odnosi się wrażenie, że faktyczne znaczenie nauk szczegółowych w filozofii Schelera nie zostało przez niego w pełni ujawnione i docenione w imię metodologicznej czystości przedstawionego przez niego modelu.

Filozofia Schelera nie jest skończonym projektem. Dlatego może ona być tylko punktem wyjścia do dyskusji dotyczącej różnych aspektów relacji między filozofią i nauką. Mimo to jako całość budzi podziw rozmachem wizji, zaś w niektórych fragmentach - precyzją szczegółów. Widać w niej Nietzscheański ,głęboki respekt dla misterności rzeczy".

\section{Literatura}

Bocheński J.M. [1992], Współczesne metody myślenia, Wydawnictwo „W drodze”, Poznań.

Haeffner G. [2006], Wprowadzenie do antropologii filozoficznej, przeł. W. Szymona OP, WAM, Kraków.

Humboldt W. von [2002], O jezzykoznawstwie porównawczym w odniesieniu do różnych epok rozwoju jezzyka [w:] O myśli i mowie, tłum. E. M. Kowalska, PWN, Warszawa.

Husserl E. [1901], Logische Untersuchungen, M. Nijhoff, Den Haag, t. 1-2.

Kant I. [2001], Uzasadnienie metafizyki moralności, przeł. M. Wartenberg, Antyk, Kęty.

Scheler M. [1987a], Człowiek i historia [w:] Pisma z antropologii filozoficznej i teorii wiedzy, tłum. S. Czerniak i A. Węgrzecki, PWN, Warszawa.

Scheler M. [1987b], Formy wiedzy i kształcenia [w:] Pisma z antropologii filozoficznej i teorii wiedzy, Warszawa.

Scheler M. [1987c], O idei człowieka [w:] Pisma z antropologii filozoficznej i teorii wie$d z y$, Warszawa.

Scheler M. [1987d], Światopoglad filozoficzny [w:] Pisma z antropologii filozoficznej i teorii wiedzy, Warszawa.

Węgrzecki A. [1975], Scheler, Wiedza Powszechna, Warszawa. 


\section{The Place of Specialised Sciences in Max Scheler's Philosophy with a Particular Focus on Philosophical Anthropology}

(Abstract)

The aim of the article is to clarify the nature of the cooperation between philosophy and specialised sciences proposed by Scheler. Reflections on types of cognition lead to the conclusion that neither the facts nor the methods of specialised sciences can be directly used by philosophy. The former must be 'cleared' of the assumptions that burden them and of all kinds of 'insertions'. The latter may perform an auxiliary role at best, as the main burden of responsibility for philosophical cognition rests on the phenomenological method. It consists of successively conducted reductions (transcendental, psychological, eidetic), which are to open us to the space of pure possibility. Scheler's himself does not always consistently implement his methodological postulates. In practice, he often refers to the facts of specialised sciences and makes inductive generalisations concerning problems of a philosophical nature. A phenomenological experience which is precisely executed, free of assumptions, and essence-oriented is, therefore, not the only source of the theses he supports.

Keywords: specialised sciences, naturalistic conceptions of man, methods and forms of cognition, types of knowledge, phenomenological method. 